(C) [2009] IEEE. Reprinted, with permission, from [Janet Xin Ge and Grace K C Ding, Cost Effective and Sustainable? : Photovoltaic (PV) Rebate Program in Australia, Management and Service Science, 2009. MASS '09. International Conference on , 20-22 Sept. 2009]. This material is posted here with permission of the IEEE. Such permission of the IEEE does not in any way imply IEEE endorsement of any of the University of Technology, Sydney's products or services. Internal or personal use of this material is permitted. However, permission to reprint/republish this material for advertising or promotional purposes or for creating new collective works for resale or redistribution must be obtained from the IEEE by writing to pubs-permissions@ieee.org. By choosing to view this document, you agree to all provisions of the copyright laws protecting it 


\title{
Cost Effective and Sustainable?
}

\author{
Photovoltaic (PV) Rebate Program in Australia
}

\author{
Janet Xin Ge \\ School of the Built Environment \\ University of Technology, Sydney \\ Sydney, Australia \\ Xinjanet.ge@uts.edu.au
}

\author{
Grace K C Ding \\ School of the Built Environment \\ University of Technology, Sydney \\ Sydney, Australia \\ Grace.ding@uts.edu.au
}

\begin{abstract}
The Australian Government has recently announced a Renewable Energy Target (RET) scheme to provide up front payments of $\$ \mathbf{8 , 0 0 0}$ for around $\mathbf{2 5 , 2 5 0}$ households of income less than $\$ 100,000$ per year installing a 150 watt solar panel system starting on 01 July 2009 using \$202 million taxpayers' money. The scheme has not included households' with incomes greater than $\mathbf{\$ 1 0 0 , 0 0 0}$, nor developers who produce new houses. Whether the policies are effective and sustainable is arguable. This paper examines policies designed to encourage households to install solar panel system in Australia and demonstrates reasons for supporting developers to build green houses using Net Present Value (NPV) analysis in a case study. The findings suggest that the government should support installation of solar systems by both households and the developers.
\end{abstract}

Keywords-Sustainable; Renewable Energy; Solar System; DCF, Households, Developers, Australia

\section{INTRODUCTION}

The renewable energy supply scheme is one of the important agendas for all levels of government around the world. This is because conventional types of energy supply not only damage the environment, e.g., from emissions of chemical pollutants into air, water and soil; both at construction and during operation; but also damage to human health [1]. The Australian government has formulated strategies and taken actions to address the issues of global warming and climate change to reduce greenhouse gases emissions by supporting the deployment of renewable energy in Australia's electricity supply since 2001 when a Mandatory Renewable Energy Target (MRET) scheme was introduced. The scheme aims to increase the uptake of renewable energy in Australia's electricity supply. In 2007, the Government committed itself to ensuring that 20 percent of Australia's electricity supply comes from renewable energy sources by 2020. To deliver on this commitment, the Government is working in cooperation with the states and territories through the Council of Australian Governments (COAG), to implement an expanded national Renewable Energy Target (RET) that will bring the MRET and existing and proposed state and territory targets into a single national RET scheme [2]. The expanded Renewable Energy Target (RET) scheme, aims to produce 45,000 Gigawatt hours of renewable electricity per year, four times (9,500 Gigawatt hours per year) greater than the target in 2010, set by the Mandatory Renewable Energy Target (MRET) scheme started on 1 April 2001 [3]. The main federal programs are listed in the Table 1. Among the federal programs, there are allocated \$202 million in rebates for households that install small solar panels. Each household is eligible to receive government rebates of up to $\$ 8,000$ for installing solar panels in their property provided they own it and use it as their principal place of residence effective on 01 July 2009. However, households with incomes above $\$ 100,000$ are prevented from receiving the rebate [4]. Property developers completing 100,000 new houses have also been ruled out from the program. There are arguments about whether the program will be a cost effective way to develop a sustainable renewable energy system. This paper examines the policies designed for households to install solar panel in Australia and demonstrates reasons for supporting developers to build green houses using Net Present Value (NPV) analysis in a case study. The findings suggest that government should support both households and developers to build sustainable green houses. The paper is organised as follows: Firstly, it reviews Australian photovoltaic (PV) subsidy program and compare the renewable energy schemes with other countries. Secondly, it demonstrates a need to support developers installing solar systems into new developments in a case study using NPV analysis. Thirdly, it comments on problems in current solar subsidy programs.

TABLE 1. THE RET SCHEME IN AUSTRALIA

\begin{tabular}{|l|l|l|}
\hline Clean Coal Fund & $\begin{array}{l}\text { \$500 } \\
\text { million }\end{array}$ & $\begin{array}{l}\text { To help industry develop clean-coal } \\
\text { technologies }\end{array}$ \\
\hline $\begin{array}{l}\text { Renewable Energy } \\
\text { Fund }\end{array}$ & $\begin{array}{l}\$ 500 \\
\text { million }\end{array}$ & $\begin{array}{l}\text { For industry to develop renewable } \\
\text { energy technology }\end{array}$ \\
\hline Solar Schools Plan & $\begin{array}{l}\$ 481 \\
\text { million }\end{array}$ & $\begin{array}{l}\text { For schools to install solar panels and } \\
\text { improve energy and water efficiency }\end{array}$ \\
\hline Green Loans & $\begin{array}{l}\$ 300 \\
\text { million }\end{array}$ & $\begin{array}{l}\text { In subsidized loans for households to } \\
\text { install solar hot water, insulation, } \\
\text { rainwater tanks and green water } \\
\text { recycling }\end{array}$ \\
\hline $\begin{array}{l}\text { Photovoltaic Rebate } \\
\text { Program }\end{array}$ & $\begin{array}{l}\text { \$n rebates for households installing solar } \\
\text { million } \\
\text { panels }\end{array}$ \\
\hline $\begin{array}{l}\text { Low Emission Plan } \\
\text { for Renters }\end{array}$ & $\begin{array}{l}\text { \$150 } \\
\text { million }\end{array}$ & $\begin{array}{l}\text { For rebates to landlords insulating rental } \\
\text { properties. }\end{array}$ \\
\hline
\end{tabular}
Source: Davis (2008) [5] 


\section{REVIEWING PV RENEWABLE ENERGY SCHEME}

Renewable energy generation is a long-term strategy and development of a robust industry because of higher cost compared to conventional fossil fuel electricity generation. Solar photovoltaic technology has become popular as it generates energy directly from sunlight. Government must step in to provide promotion instruments and support the involvements of industries and households as installation costs are high. Many countries have adopted necessary measurements to tackle the issues though many differences between these countries, such as natural resource endowments, political and economic systems and cultural traditions [6]. Table 2 is a summary of the policies used by these countries.

TABLE 2. SOLAR SUBSIDY PROGARM AMONG COUNTRIES

\begin{tabular}{|c|c|}
\hline Country & Photovoltaic Energy Subsidy Program \\
\hline $\begin{array}{l}\text { Australia } \\
\text { - PV rebate program }\end{array}$ & $\begin{array}{l}\text { - subsidize households for PV installation } \\
\text { - Renewable Energy Certificates (RECs) }\end{array}$ \\
\hline $\begin{array}{l}\text { Japan } \\
\text { - Net metering } \\
\text { - 70,000 solar roofs with } \\
\text { investment subsidies (1994) } \\
\text { - PRS (2002) } \\
\end{array}$ & $\begin{array}{l}\text { - sets parameters for connecting small } \\
\text { distributed PV \& wind systems to the grid. } \\
\text { - encourage the use of PV systems in } \\
\text { residences. } \\
\text { - educate consumers about PV technology. }\end{array}$ \\
\hline $\begin{array}{l}\text { U.S. } \\
\text { - Energy Tax Act } 1978 \\
\text { - Extended to } 1985 \text { \& } 1988 \\
\text { - PURPA }\end{array}$ & $\begin{array}{l}\text { - } 10 \% \text { tax credit for business investment in } \\
\text { wind, solar, geothermal, \& ocean thermal. } \\
\text { - required utilities to buy power from } \\
\text { renewable producers. } \\
\text { - purchase price for power at utilities } \\
\text { 'avoided cost', which was defined by the } \\
\text { States. } \\
\text { - purchase incentive for private energy } \\
\text { producers. }\end{array}$ \\
\hline $\begin{array}{l}\text { Germany } \\
\text { Electricity Feed-In Law (1991) } \\
\text { Renewable Energy Law (2000) }\end{array}$ & $\begin{array}{l}\text { - obligated utilities to buy power from } \\
\text { renewable producers. } \\
\text { - purchase price for power was } 90 \% \text { of the } \\
\text { retail rate. }\end{array}$ \\
\hline $\begin{array}{l}\text { Denmark } \\
\text { - Investment subsidy (1979-89) } \\
\text { - Production subsidy \& other } \\
\text { support mechanism (1981 \& } \\
\text { 1992) }\end{array}$ & $\begin{array}{l}\text {-30\% capital grant to individuals who } \\
\text { installed wind, solar or biogas digesters. } \\
\text { - additional production incentive for private } \\
\text { renewable energy producers. } \\
\text { - law obligated utilities to buy power from } \\
\text { renewable producers. } \\
\text { - law set utilities’ purchase price for power } \\
\text { at } 85 \% \text { of the retail rate. }\end{array}$ \\
\hline $\begin{array}{l}\text { Netherland } \\
\text { Demand-Pull Ecotax system } \\
\text { (2000) }\end{array}$ & $\begin{array}{l}\text { Exempt renewable energy from Ecotax to } \\
\text { encourage consumers to choose green } \\
\text { power. }\end{array}$ \\
\hline
\end{tabular}

Source: Energy Information Administration (2005) [6]

Japan has been one of the countries that have implemented an aggressive successfully solar PV program beginning in the 1990s. The Japanese government has taken four actions to:

- $\quad$ provided net metering guidelines to dictate how distributed PV generation would be hooked up to the national electricity grid;

- set an ambitious goal for the development of 4,600MW of PV by 2010;

- introduced subsidies to support the installation of PV technology;

- established the 70,000 solar roofs program to encourage residential use of $\mathrm{PV}$ and to inform people about the benefits of using PV technology.
The government programs are aimed to reduce the cost of installing PV systems by subsidizing the installation costs of residential systems. The subsidies are available not only for homeowners installing their own PV systems, but also for suppliers of ready-built houses, for public organizations to introduce systems into public buildings and for connecting PV systems to low voltage lines on the power grid. Between 1994 and 2000, PV systems were installed in more than 50,000 houses [6].

The U.S. government used financial incentives to encourage the growth of renewable energy aimed to promote energy efficiency. The 1978 Energy Tax Act (ETA) included a 10 percent tax credit for business investments in solar, wind, geothermal and ocean thermal technologies. Net metering programs were designed for small electricity customers to sell their power back to the grid. The buyback rate is determined by law at utilities 'avoided cost', which is defined by the States [6].

The Germany government has targeted the use of renewable resources. The "1,000 Roof" program was successful in 199294, a further " 100,000 Solar Roofs" program was introduced in 1999 to increase PV capacity from less than 50 MW installed in 1997 to about 400 MW installed by year-end 2003. The program provides low-interest loans for PV systems. The Electricity Feed-In Law (1991) and Renewable Energy Law (2000) specified that energy utilities are obligated to buy renewable electricity from producers and the purchase price for power was 90 percent of the retail rate for electricity. The Creation of a market for renewable electricity and guaranteed producers of renewable electricity at a sustainable price high enough to cover the long-term costs were the two important factors to attract renewable energy investment in Germany [6].

Solar collectors are much more common in other countries. Denmark's investment subsidy allowed individuals to be reimbursed for capital costs of wind, solar panels and biogas digesters. The Netherland' Ecotax system pursues a demandpull approach to encourage consumers to buy renewable energy by exempting the Ecotax for all green power purchases and subsidy for green power producers. Israel requires all new homes and apartments to use solar water heating. In Cyprus, over 90 percent of homes have solar water heaters [7].

Similar to Germany, the Australian government aims to increase the use of renewable energy in Australia by introducing a Photovoltaic Rebate Program to encourage the long-term use of PV technology to generate electricity from sunlight [8]. The program provides large cash rebates to a maximum of $\$ 8,000$ to homeowners who install new PV power systems on their principal place of residence. However, households with a taxable family income of $\$ 100,000$ or more are ineligible for the rebate. The program covers only households with existing houses and does not include developers of new houses, a policy different from these of other countries. 


\section{ANALYSIS OF COST AND SUSTABLITY OF EXTENDING THE SUBSIDY PROGRAM TO DEVELOPERS}

Australia has an average 7.2 hours of sunshine each day [9], which provides a perfect environment for developing solar power technology. Though the current solar panel rebate appears to generate a high demand in Australian homes, the solar industry has claimed that their millions of dollars in investment are at risk because the future of solar rebates and alternative methods of subsidizing solar panels are unclear. A feed-in tariff based on the German model has been suggested [10]. Developers that produce new houses are not included in the rebate program. This section demonstrates the reasons for government to support developers that build green houses by presenting a NPV analysis on a development project.

\section{A. A Robust Way to Develop Solar by Supporting Developers}

Statistics shows that more than $90 \%$ of the energy used by NSW households is generated by burning coal and an average household causes eight tons of harmful carbon dioxide every year [11]. The use of solar panel system in houses is one of the methods to generate renewable energy. There are averages of 100,000 new houses commenced and completed each year around Australia. Figure 1 depicts commenced and completed new houses since 1981 in Australia (three quarters in 2008). Obviously, if $25 \%$ of the new completed houses have been installed solar systems, Australian government will achieve the $20 \%$ of target renewable energy supply easily.

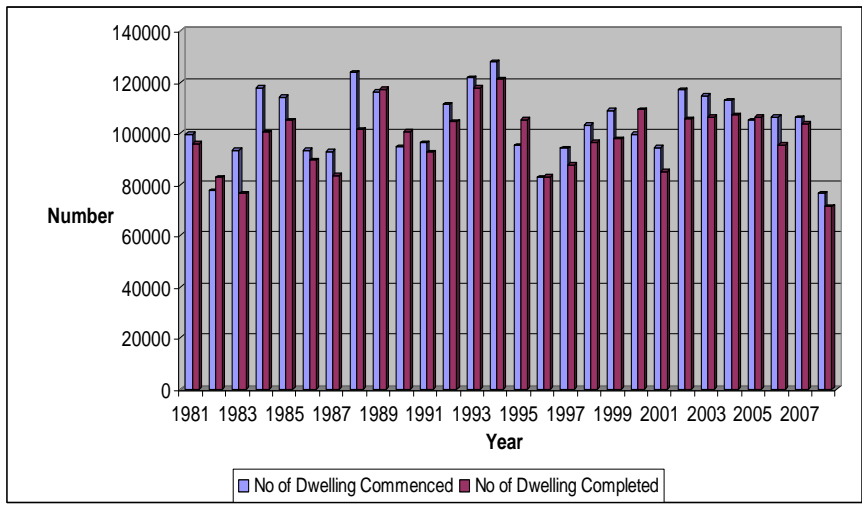

Figure 1. Number of dwelling commenced and completed in Australia

Currently, all States in Australia require new designed homes to meet minimum thermal performance standards, i.e., to reduce the amount of fossil fuels burned to produce energy for homes, thereby reducing Australia' greenhouse gas emissions. All dwellings must achieve at 4-5 star thermal performance standards, which is regulated by the Building Code of Australia (BCA), except NSW. In NSW, the Building Sustainability Index (BASIX) overrides the BCA requirements and sets the required levels of environmental performance in a number of areas including energy, water and thermal performance. Under BASIX, a new home must be designed to use $40 \%$ less water and $40 \%$ less energy than the similar types of buildings in order to receive development approval [12].
To meet the BASIX requirements, developers must work hard within their budgets as additional costs are required to accord with the BASIX requirements. As a result of budget constraints, solar panel systems are usually not included in their design of new houses. However, developers may be encouraged to install solar technology for new houses if there is an incentive scheme provided by government. To demonstrate the issue, a development project in 2008 at Bankstown, NSW is used as a case study.

Bankstown is a suburb located around $20 \mathrm{~km}$ southwest of Sydney's CBD with 27,972 people. The predominant age group in Bankstown is 20-59 years. Average weekly household income is \$700-\$799 per week with a median price of $\$ 264,500$ for units [13]. The development site of $1,650 \mathrm{~m}^{2}$ was acquired for $\$ 1.15$ million and the proposed building of a low rise, medium density apartment building that consists of 13 apartments, i.e., one three-bedroom, ten two-bedrooms and two one-bedrooms with 20 parking spaces. Total construction costs were 2.373 million. The project financed through joint venture with the land owner and builder and discounted rate is $13.8 \%$. The property will be constructed for two years and planned to rent the apartments out for the low to moderate income families for 10 years under government affordability scheme and then sold to the market. Building approval has been granted as the design meets BASIX requirements, but without a solar panel system. An investment decision is based on Net Present Value analysis (NPV) and Internal Rate of Return (IRR). The calculation of NPV is denoted as follows:

$$
N P V=\sum_{t=1}^{n} \frac{C_{t}}{(1+k)^{t}}-C_{0}
$$

$$
\begin{aligned}
& C_{t}=\text { net cash flow generated by the project at time } t \\
& C_{0}=\text { initial cash outlay } \\
& n=\text { the life of the project } \\
& k=\text { cost of capital [14] }
\end{aligned}
$$

The NPV suggests that the project be accepted as the NPV is positive and the IRR is greater than the required rate of return. Assume now that the developer installs equivalent $13 x 8$ 150 watt solar panels and accessories which total cost $\$ 230,600$ [15]. The NPV of the developer reduces to $\$ 119,609$ from $\$ 290,061$ that the project is less profitable. However, if government provides tax credit of $\$ 7,500$ for each apartment, as it does to households, the developer may be attracted by the project as that would lead to a higher the NPV and IRR. Table 3 shows the results for the proposed project. Government policies on supporting developers plays important role for a decision to design and build sustainable green houses.

TABLE 3. NPV AND PROFITS OF THE PROJECT

\begin{tabular}{|c|c|c|}
\cline { 2 - 3 } \multicolumn{1}{c|}{} & NPV & Internal Rate of Return \\
\hline Without Solar & $\$ 290,061$ & $19.7 \%$ \\
\hline Install Solar without Rebate & $\$ 119,609$ & $16.0 \%$ \\
\hline Install Solar with Rebate & $\$ 430,834$ & $21.8 \%$ \\
\hline
\end{tabular}

Benefits of including developers in the subsidy program for solar renewable energy are as follows: 
- Install solar to the new houses help government to achieve the targets for generating and using renewable energy and reducing green house gas emission.

- Developers are in a better position to reduce the costs of construction by designing solar panel system to be installed as a component into the house design, especially for apartments.

- The installation of solar systems to new houses may be added to the BASIX requirements that improve green home standard under current regulations.

- $\quad$ The government does not have to subsidy households of new houses as solar systems have been installed by developers.

- Solar panel and related industry may benefit from a stable demand and the cost of solar panels be reduced due to economies of scale and new technology.

- The green houses with solar technology may change market perceptions and gradually change the households' purchasing behavior.

\section{B. The Current Solar RebateProgram Is Not Sustainable}

The Australian government budgets \$202 million for subsidizing households up to $\$ 8,000$ to install solar panels. This implies that around 25,250 households will be benefited from the program. A standard family with two adult and two kids and a family income less than $\$ 100,000$ are normally with tight budget. To invest in 8 _150 watt solar panels to generate sufficient electricity to power lights and appliances in a small two or three bedroom home, or about half the power in a typical energy-efficient home [14] will normally require $\$ 16,200$ excluding installation. Assume $\$ 7,500$ rebate is granted, the household is required to invest $\$ 8,600$ plus installations. If a family wants to get a bigger solar panel to provide sufficient electricity to their home, they have to pay around \$20,400 plus installation after rebate. No all families have savings for such investments. Though the government provides low interest loans [2] to encourage families to take up solar systems, the additional interest expenses will add burdens to the families, especially at current market conditions. There are also some on going expenses [16] such as maintenances which need to be added in to family' budget. The government may have to also provide additional money to compensate for the low interest loans.

\section{SUMMARY AND CONCLUTIONS}

This paper has explained the photovoltaic rebate program provided by the Australian government. The similar solar panel subsidy programs in other countries, such as US, Germany and Japan have been reviewed and compared to the Australian policies. The study has also presented a development project using NPV analysis to demonstrate the benefits and importance of supporting developers for promoting the use of solar energy and encouraging sustainable renewable energy industry by installing solar system into new developing houses. The costs of the current solar rebate program have been discussed. The research concludes that government will have long-term benefits by providing subsidy to the house developers. The solar policies should include not only households but also developers.

\section{REFERENCES}

[1] The European Wind Energy Association, "Support schemes for renewable energy: a comparative analysis of payment mechanisms in the EU”, Directorate-General Energy and Transport, 2002.

[2] W. Gerardi, "Benefits and costs of the expanded renewable energy target”, Report to Department of Climate Change, McLennan Magasanik Associates, J1640 Preferred Option Report V5, January 2009.

[3] Department of Climate Change, "Legislation and the renewable energy regulator: expanded national renewable energy target (RET) scheme”, at http://www.climatechange.gov.au/renewabletarget/legislation.html Accessed on 03/03/2009.

[4] P. Garrett, "Solar panel rebates, renewable energy", E \& OE Transcript, Interview sky news agenda program, 19 May 2008, at www.environment.gov.au/minister/garrett/2008pubs/tr20080519.pdf. Accessed on 03/03/2009.

[5] M. Davis, "Shadow falls over solar panels", Sydney Morning Herald, 3 September 2008 at http://www.smh.com.au/news/environment/. Accessed on 05/03/2009.

[6] Energy Information Administration, "Plicies to promote non-hydro renewable energy in United States and selected countries”, Feburary 2005, at http://www.eia.doe.gov/fuelrenewable.html, Accessed on 08/03/2009.

[7] Grinning Planet, "The house of the rising sun power: can a home solar energy system fit your budget?” 2004. Accessed on 03/03/2009 at http://www.grinningplanet.com/2004/05-06/home-solar-energy-systemsarticle.htm.

[8] Department of Environment, Water, Heritage and the Arts, "Solar homes and communities plan: guidelines for residential applicants”, Australian Government, 2008, at www.environment.gov.au/rebates. Accessed on 02/03/2009.

[9] Bureau of Meterorology, "Daily weather observations”, various months, Australian Government, Accessed on 04/03/2009 at http://www.bom.gov.au/products/IDN10064.shtml.

[10] M. Fyfe, "Solar rebates go sky high", October 2008, Accessed on 03/03/209 at http://www.brisbanettimes.com.au/national/solar-rebatesgo-sky-high/2008/10/18/1224351016909.html.

[11] Department of Energy, Utilities and Sustainability, "NSW renewable energy target”, NSW Annual Planning Report 2006, Explanatory Paper, New South Wales Government, November 2006.

[12] Department of Planning, "The BASIX”, New South Wales Government, Australia at http://www.basix.nsw.gov.au/information/index.jsp, Accessed on 02/03/2009.

[13] Australian Property Monitors (APM), Bankstown profile, 2007. Accessed on 02/03/09 at www.apm.com.

[14] G. Peirson, R. Bird, R. Brown and P. Howard, "Business Finance", $6^{\text {th }}$ edition, McGraw-Hill, 1995.

[15] Solazone, “Aussie Powermakers”, 2009. Accessed on 24/02/2009 at http://www.solazone.com.au/SOLPOWER.htm.

[16] Wikipedia, "Photovoltaic module", Accessed on 24/02/2009 at http://en.wikipedia.org/wiki/Photovoltaic module. 